Marine Geology

November 2005; 222-223 : 299-311

http://dx.doi.org/10.1016/j.margeo.2005.06.018

(c) 2005 Published by Elsevier B.V.
Archimer, archive institutionnelle de l'Ifremer http://www.ifremer.fr/docelec/

\title{
Seismic stratigraphy of the Deglacial deposits of the Rhône prodelta and of the adjacent shelf
}

\section{Caroline Labaune $^{\mathrm{a}^{*}}$, Gwenael Jouet ${ }^{\mathrm{b}}$, Serge Berné ${ }^{\mathrm{b}}$, Bernard Gensous $^{\mathrm{a}}$, Michel Tesson ${ }^{\mathrm{a}}$ and Arnaud Delpeint ${ }^{b}$}

\author{
aUniversité de Perpignan, Laboratoire de Biophysique et Dynamique des Systèmes Intégrés, 52 avenue Paul \\ Alduy, 66860 Perpignan, France \\ ${ }^{\mathrm{b}}$ Ifremer, DRO/GM Technopôle Brest-Iroise, P.O.Box 70, 29280, Plouzané, France \\ *: Corresponding author : Tel.: +33 336666821 12. labaune@univ-perp.fr
}

\begin{abstract}
In order to achieve a synthesis of the stratigraphic organization of the Deglacial deposits of the inner/middle shelf in front of the Rhône delta plain, we merged high resolution (Mini-sparker and Sparker), and very high resolution (chirp and mud-penetrator) seismic data into a single seismic database. Thus, the merged seismic database improves the lateral correlation between eastern and western parts, separated by the Rhône Incised Valley deposits. As a result the interpretation of seismic units in relation to local and global environmental changes was refined.

The Deglacial deposits rest on a basal erosional discontinuity capping a complex of Pleistocene prograding wedges. The identified units make up Transgressive and Highstand Systems Tracts, and are bounded by flooding surfaces. The main flooding surfaces are (1) the transgressive surface (D200) which forms the lower boundary of the Deglacial deposits and (2) the maximum flooding surface which forms the boundary between the Transgressive and Highstand Systems Tracts. Regarding the data set the study area is divided into three parts depending on the stacking pattern and main control factors. In the western area the units present an aggradational stacking pattern and the rate of sediment supply and dynamic conditions seems coupled with glacio-eustacy role on sedimentary units building and evolution. In the central area the units present an overall backstepping pattern mainly controlled by glacio-eustacy. In the eastern area the units present an aggradational stacking pattern and both the glacio-eustacy and rate of sediment supply have an important role.

The lower parasequence of the Transgressive Systems Tract (U200) is due to the reworking of Würmian terraces. Above, the parasequence U300 is a transgressive body formed during a rapid sealevel rise. The two upper parasequences are interpreted as ancestral coastal systems with a backstepping pattern. The first coastal system (U400) is due to a decrease in the rate of sea-level rise that occurred during the Younger Dryas. The second coastal system (U500) may be due to a similar event or to an increased rate of sediment supply during a constant sea-level rise.

Finally the Highstand Systems Tract is composed of three units: (i) unit U601, located to the West and interpreted as a subaqueous delta, (ii, iii) units $\mathrm{U} 600$ and U610, located to the East and interpreted as prograding deltaic lobes.
\end{abstract}

Keywords: Rhône shelf; Deglacial deposits; seismic stratigraphy; glacio-eustacy; sediment supply 


\section{Introduction}

During the last three decades, Deglacial deposits of shelf areas have been the field of numerous geological studies. On many inner continental shelves, shallow water depth and landward thickening prisms, several tenths of meter thick, provide expanded records of Deglacial deposits. The Rhône continental shelf, in particular, allows detailed analysis of various local and global factors controlling formation of depositional sequences formed during the last post-glacial hemicycle.

Several previous works deal with the Deglacial deposits of the northern part of the Gulf of Lions, including Aloisi et al. (1975); Marsset and Bellec (2002) and Gensous and Tesson (1997, 2003). Those papers defined a set of progradational, aggradational and/or backstepping units. Some differences appear about the extension of the transgressive units and essentially about the interpretation and identification of the upper units of the prodelta system.

Through the Eurodelta European concerted action (Trincardi, 2003), the main prodeltas of the northern Mediterranean Sea and Black Sea are objects of synthesis of previous works and data. In this context, a synthetic study of the Deglacial Rhône prodelta and adjacent shelf deposits was done, using a large seismic database. The present study is based on the analysis of high and very high resolution (HR and VHR) seismic data acquired both by Ifremer and Perpignan University (GDARGO) on the inner and middle shelf of the northern part of the Gulf of Lions (Fig. 1).

The objectives were to achieve a synthesis of the stratigraphic organization of the Deglacial deposits, to improve the lateral correlation between eastern and western parts of the delta system, and to refine the interpretation of seismic units in terms of genetic factors.

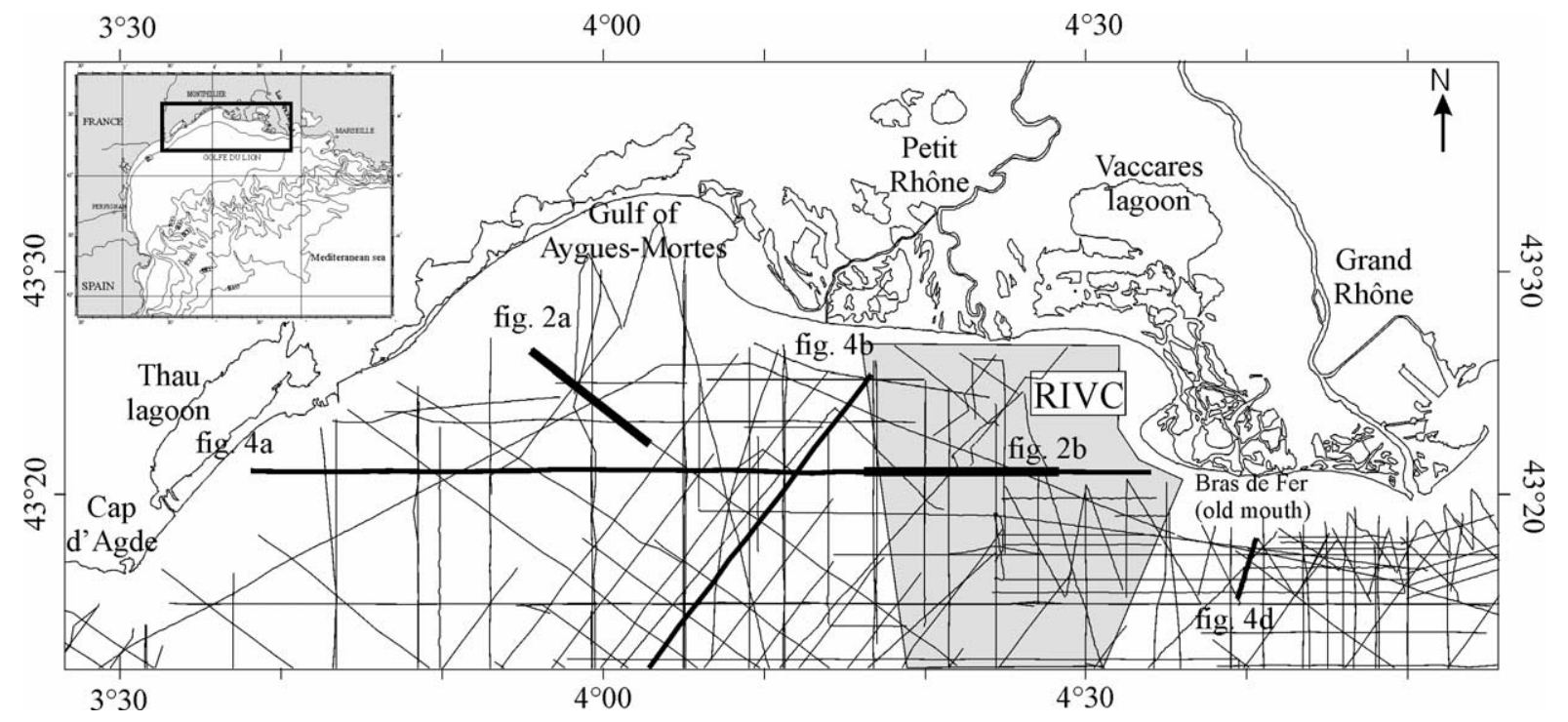

Fig. 1. Map of the northern part of the Gulf of Lion and location map of seismic sections acquired both by Ifremer and Perpignan University (GDARGO). The grey area indicates the location of the Rhône Incised Valley Complex (RIVC) which delimits the eastern from the western area.

\section{Regional setting}

The Gulf of Lions is a siliciclastic passive margin stretched between the Pyrenean and Alpine orogenic belts in the Northern part of the Western Mediterranean Basin (Fig. 1). The development of the margin was initiated by Oligocene rifting (Gueguen, 1995; Sioni, 1997) followed by oceanic opening during the Miocene (Speranza et al., 2002). The accumulation of the 


\section{Labaune et al./ Marine Geology xx (2005) xxx-xxx}

sedimentary wedge mainly occurred during the Plio-Quaternary period, principally controlled by gla-cio-eustacy (Bessis, 1986).

The Gulf of Lions is a wave-dominated area with, at the shoreline, extensive sand barriers isolating shallow lagoons (be'tangsQ). The Rhône sediment supply represents 80\%, about 7.410 tons/yr, of the total sediment budget to the continental shelf (Pont et al., 2002) and forms a large delta system. At the coast, the southeasterly dominant wave-regime drives a southwestward longshore drift. The general oceanographic circulation is dominated by the geostrophic LiguroProvencal current (Millot, 1994). The specific study area is bounded at the South by the $43^{\circ} 15$ parallel.

From the mid-shelf to the shelf break, Pleistocene deposits are represented by a complex of superimposed prograding wedges thickening seaward. Those wedges are interpreted as prodeltaic deposits (Aloı"si, 1986; Tesson and Allen, 1995; Rabineau et al., 1998) that accumulated during falling-stage and lowstand sea-level episodes (Tesson et al., 2000; Posamentier et al., 1992). In the central part of the study area, the Pleistocene deposits are interrupted by an important incised valley system: the Rhône Incised Valley Complex - RIVC (Fig. 1). It extends from the deltaic plain down to the Petit Rhône canyon. The RIVC formed by successive Quaternary eustatic cycles (Tesson and Allen, 1995). The stacking pattern of Pleistocene units differs between the western and eastern parts of the RIVC. In the western area, some well-developed intercalated units appear between the prograding wedges at the mid/outer shelf. They represent nearshore sand bodies that accumulated either during the periods of maximum relative sea level lowstand and/ or during stillstands that occurred during overall sea-level rises (Berne et al., 1998; Rabineau et al., 1998; Tesson et al., 2000).

\section{Data and methodology}

The location map of all seismic sections used for this study is presented in Fig. 1. The database represents both the Ifremer and the University of Perpignan seismic data collected since 1990. The $5000 \mathrm{~km}$ seismic data comprise high resolution (HR) profiles, acquired with a mini-sparker (50 J) and a sparker (700 J). Very high resolution (VHR) seismic data were acquired with a chirp system $(2-5 \mathrm{kHz})$ and a mud penetrator working at $3.5 \mathrm{kHz}$. Most of the data were digitally recorded using a Delph seismic system. Other data were recorded on analogic format, and were subsequently digitized. The navigation was based on GPS (100 m accuracy) and DGPS (about 10 m accuracy).

The following section summarizes key observations based on these data, especially on HR seismic data. The principles of seismic analysis are those described by Mitchum and Vail (1977) and Mitchum et al. (1977) who describe the key seismic facies and terminations (Fig. 2).

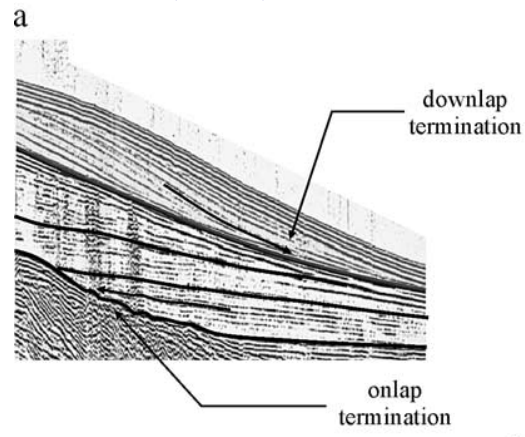

$\mathrm{b}$

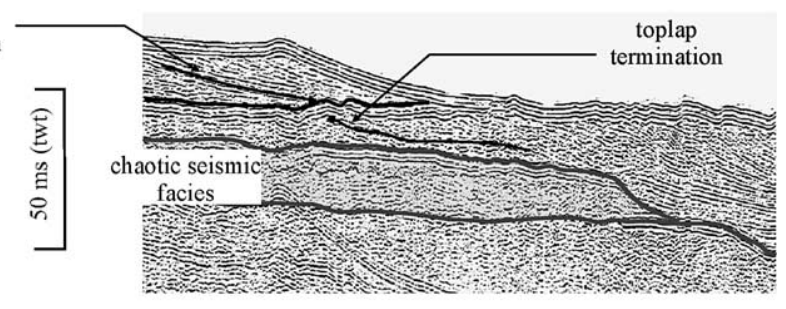

$3 \mathrm{~km}$

Fig. 2. Several types of seismic reflector terminations, after the terminology defined by Mitchum et al. (1977). 


\section{Seismic stratigraphy}

The main characteristics of seismic surfaces and units are summarized in Tables 1 and 2.

\subsection{Discontinuities}

Nine surfaces, labeled D200 to D610 from base to top, are identified through the study area (Figs. 3 and 4). Each surface is defined as regional or local depending both on their correlation with previous works and on the correlation through the seismic database used in this study. Generally, the bounding surfaces present a flat morphology, except those located in the RIVC area. The basal discontinuity, D200, is amalgamated with D300 in the western area and is well-defined in the central and eastern areas where it overlays toplap terminations. D200 is an erosional discontinuity which is correlated down to the shelf break by Gensous and Tesson (2003) and thus it is considered as a regional surface. D300 is defined by onlap terminations onto the RIVC to the east, and by coastal onlap onto Pleistocene deposits landward. The underlying reflectors show toplap terminations. It is an erosional and regional discontinuity amalgamated with D400 in the eastern area. D400 is a regional surface observed through the whole seismic database. It is an erosional discontinuity defined by toplap and essentially downlap terminations, and lateral subconcordant reflectors. The surface D401 shows toplap terminations and is observed only in the north of the Gulf of Aigues-Mortes. D402 is a downlap surface restricted to the westernmost coast. D500 is an erosional and regional surface, observed through the whole seismic database. It is characterized by toplap terminations below and downlap terminations above except in the western end of the RIVC area where it is outcropping. The upper boundary surfaces, D600 and D610, are only identified in the eastern area as downlap surfaces. D601 is an erosional discontinuity characterized by toplap terminations. It extends only in the western area. It is also a downlap surface.

Table 1. Main characteristics of seismic surfaces

\begin{tabular}{lllc} 
Surfaces & Terminations & Type & Extent \\
\hline D610 & downlap & ? & local \\
D601 & toplap/downlap & erosional & local \\
D600 & toplap/downlap & erosional & local \\
D500 & toplap/downlap & erosional & regional \\
D402 & downlap & ? & local \\
D401 & toplap & erosional & local \\
D400 & toplap/downlap & erosional & regional \\
D300 & toplap/onlap & erosional & regional \\
D200 & toplap & erosional & regional
\end{tabular}

\subsection{Seismic units}

Ten seismic units (from U200 to U610 from base to top) bounded by the above described unconformities have been identified.

Unit U200 is located in the central and eastern areas. Its maximum thickness is about $10 \mathrm{~m}$ (Fig. 5a). It erosionally overlies the deposits of the RIVC in the central area and the Pleistocene wedges in the eastern area. Its stratal pattern evolves from discontinuous reflectors or chaotic seismic facies in the axial part to continuous, slightly convex-upward reflectors which downlap eastward onto the underlying surface. 
Unit U300 is observed in the western area from the middle shelf up to $30 \mathrm{~m}$ water depth. The isopach map (Fig. 5b) shows a crescent shape with a maximum thickness of about $20 \mathrm{~m}$ in the proximal part of the unit. Its internal structure is characterized by horizontal to sub-horizontal parallel continuous reflectors onlapping landward onto Pleistocene deposits and laterally onto U200 deposits and incised valley deposits. It is a regional seismic unit.

The prograding units U400 and U500 are superimposed or slightly backstepping. Both are regional units but they mainly developed in the western and central area where they outcrop on the inner shelf between 30 and $60 \mathrm{~m}$ of water depth. In the eastern area, in front of the present Rhône river mouth, U400 and U500 are relatively thin and arranged in an aggrading pattern; the presence of gas prevents seismic penetration and further observation.

Table 2 Main characteristics of seismic units and named correspondence with previous works of Marsset and Bellec (2002) and Gensous and Tesson (2003)

\begin{tabular}{|c|c|c|c|c|c|c|c|}
\hline \multirow[t]{2}{*}{ Units } & \multirow[t]{2}{*}{ Seismic facies } & \multirow[t]{2}{*}{ Thickness } & \multirow[t]{2}{*}{ Extent } & \multirow[t]{2}{*}{ Area } & \multirow{2}{*}{$\begin{array}{c}\text { Marsset and } \\
\text { Bellec (2002) }\end{array}$} & \multicolumn{2}{|c|}{$\begin{array}{l}\text { Gensous } \\
\text { and }\end{array}$} \\
\hline & & & & & & & $\begin{array}{l}\text { Tesson } \\
(2003)\end{array}$ \\
\hline U610 & $\begin{array}{l}\text { prograding clinoforms to sub-horizontal } \\
\text { reflectors }\end{array}$ & up to $25 \mathrm{~m}$ & local & East & U8-U11 & & \\
\hline U601 & prograding sigmoids & up to $10 \mathrm{~m}$ & local & West & & $\mathrm{T} 4$ & \\
\hline U600 & $\begin{array}{l}\text { prograding clinoforms to sub-horizontal } \\
\text { reflectors }\end{array}$ & up to $10 \mathrm{~m}$ & local & East & U8-U11 & & \\
\hline U501 & sigmoid to oblique-tangential reflectors & up to $20 \mathrm{~m}$ & local & West & & & \\
\hline U500 & $\begin{array}{l}\text { prograding clinoforms to sub-horizontal } \\
\text { reflectors }\end{array}$ & up to $30 \mathrm{~m}$ & regional & West & U7 & $\mathrm{T} 4$ & \\
\hline U402 & oblique-tangential reflectors & up to $15 \mathrm{~m}$ & local & & & T3 & \\
\hline U401 & landward prograding clinoforms & up to $15 \mathrm{~m}$ & local & North-West & U6 & T3 & \\
\hline U400 & $\begin{array}{l}\text { prograding clinoforms to sub-horizontal } \\
\text { reflectors }\end{array}$ & up to $30 \mathrm{~m}$ & regional & & U5 & $\mathrm{T} 3$ & \\
\hline U300 & sub-horizontal reflectors & up to $30 \mathrm{~m}$ & bregionalQ & & U4b-U4c & & \\
\hline U200 & chaotic to continuous reflectors & up to $10 \mathrm{~m}$ & local & RIVC/East & U4a & $\mathrm{T} 2$ & \\
\hline
\end{tabular}

Unit U400 is mainly developed in front of the Gulf of Aigues-Mortes (Fig. 5c). On cross section it appears as a lenticular to prismatic body, about $30 \mathrm{~m}$ thick, thinning seaward and eastward. Seismic facies pattern is oblique-tangential with high angle toplap terminations (18to 1.58). The distal toes of clinoforms gently downlap onto the lower boundary and merge with subparallel reflectors of U300. Shoreward, the inner part of U400 is erosionally overlaid by unit U401 (Fig. 5d) showing landward prograding clinoforms. In the eastern area U400 is thin (maximum $15 \mathrm{~m}$ ) and is composed of horizontal to sub-horizontal reflectors. It rests on Pleistocene deposits or U200.

Unit U500 spreads on the inner shelf shoreward of U400. In the central area, it is a shore parallel lenticular to prismatic body (Fig. 6f), of up to $30 \mathrm{~m}$ thick, and presenting an offlap break. It shows seaward prograding clinoforms to sub-horizontal tangential reflectors. Towards the east, U500 prolongs under the modern delta plain; only the distal part of the unit, composed of horizontal to sub-horizontal reflectors, is observed on the inner shelf.

Unit U402 and unit U501 are located at the westernmost part of the study area, close to Cap d'Agde (Figs. 5e and 6g). Based on correlation of seismic profiles, they are considered as lateral equivalents of U400 and U500, respectively. Unit U402 is a lenticular body (Fig. 5e), 15 m thick, with prograding oblique-tangential reflectors onlapping onto the Pleistocene deposits. They present an accentuated dip in the proximal area.

Unit U501 (Fig. 6g) is a prismatic body up to $20 \mathrm{~m}$ thick. Its seismic facies presents sigmoid to oblique-tangential reflectors. 
Units U600 and U610 are stacked units that develop in the eastern part of the study area, in front of the Rhône delta plain (Fig. 6h). Both units are wedge shaped thinning progressively offshore and thickening landward. They show prograding oblique-tangential reflectors. Maximum observed thick- ness is $10 \mathrm{~m}$ for U600 and $25 \mathrm{~m}$ for U610 in front of the "Grand Rhône" and "Bras de Fer" mouths.

Unit 601 is the uppermost unit in the western area (Fig. 6i). It appears as a lenticular body with a maximum thickness of $10 \mathrm{~m}$. U601 shows clearly pro-grading sigmoids.

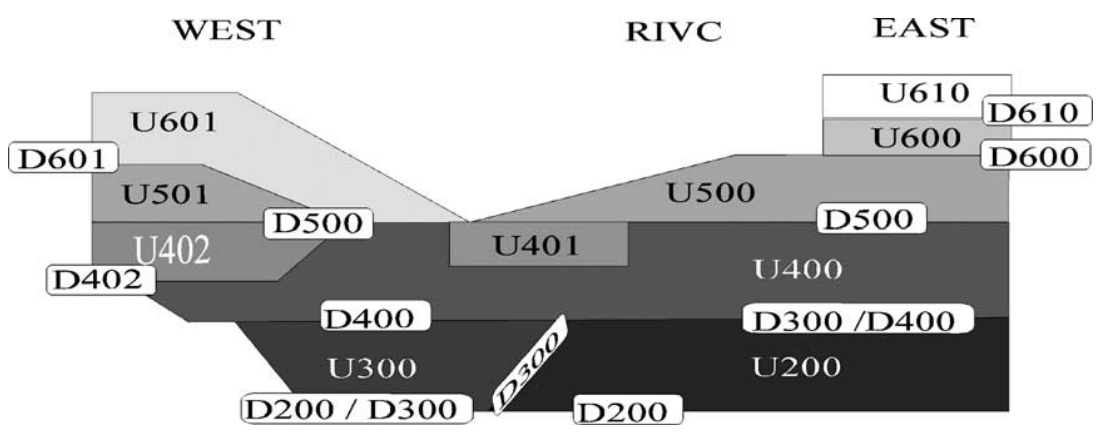

Fig. 3. Schematic stratigraphic organization of the Deglacial deposits and discontinuities in the western, RIVC and eastern parts of the study area (not scaled). 

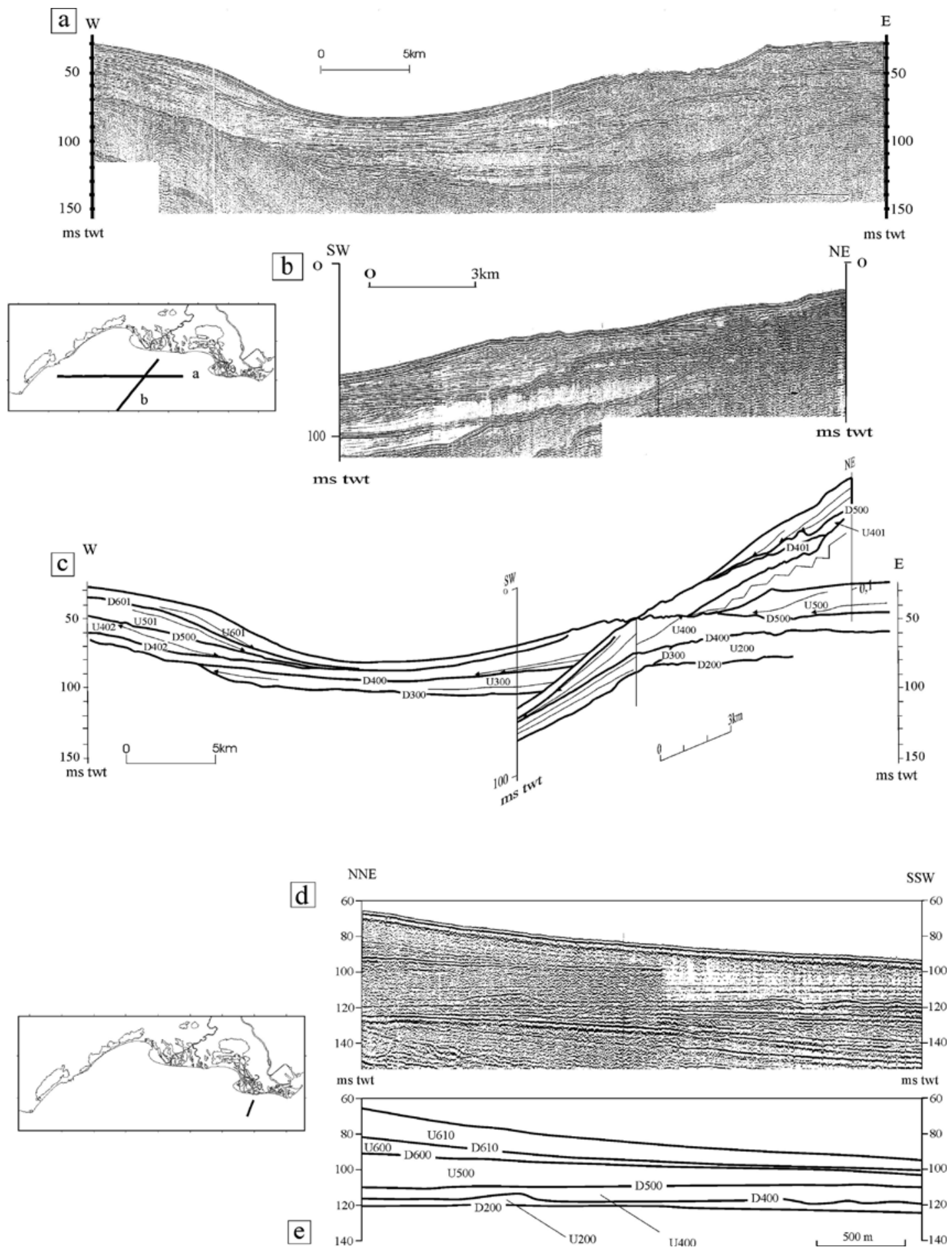

Fig. 4. Uninterpreted (a, b, d) and interpreted (c, e) seismic sections illustrating the main units and discontinuities, respectively, in the western area $(a, b, c)$ and eastern area (d, e). 

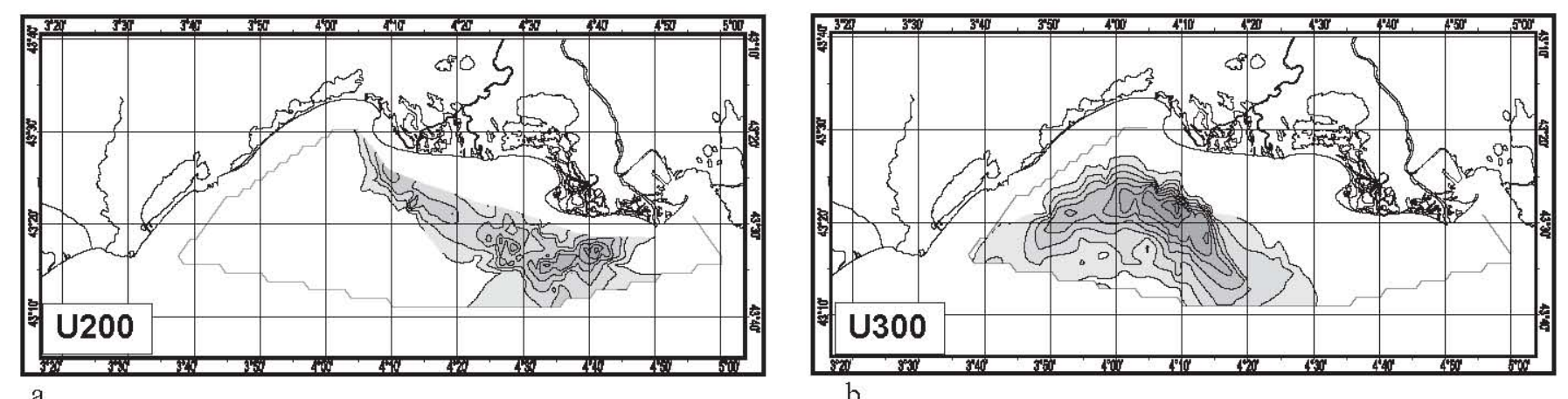

${ }_{\text {Mercato - WGS } 84}^{10 \quad 20} \mathrm{KM}$
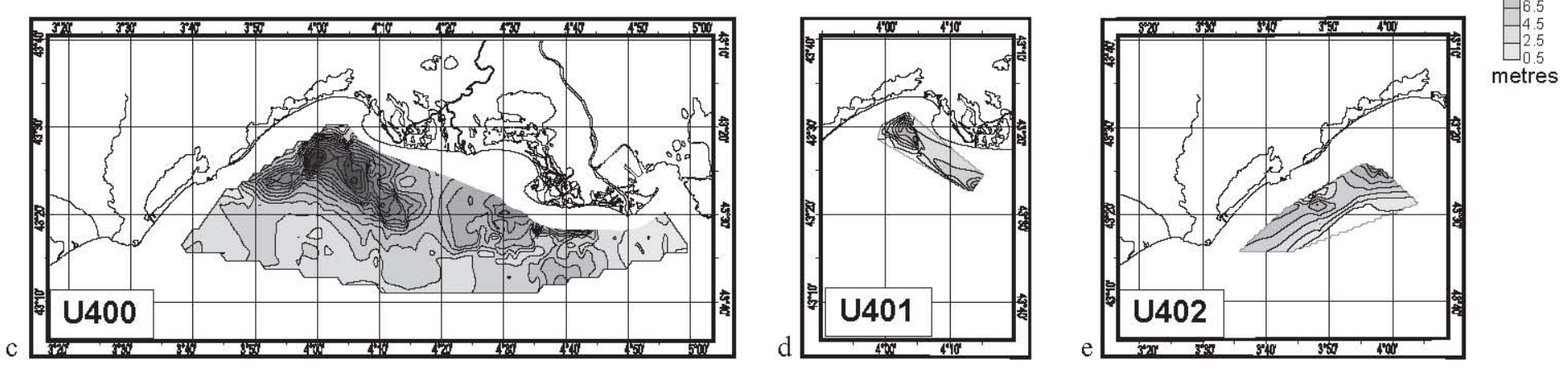

Fig. 5. Isopach maps of some of the units identified in the Rhône prodelta and adjacent shelf. The isopach maps from the basal to the fifth unit identified (from a to e) are here shown. Thickness in meters, based on an acoustic waves velocity of $1600 \mathrm{~m} / \mathrm{s}$ in sediment. 

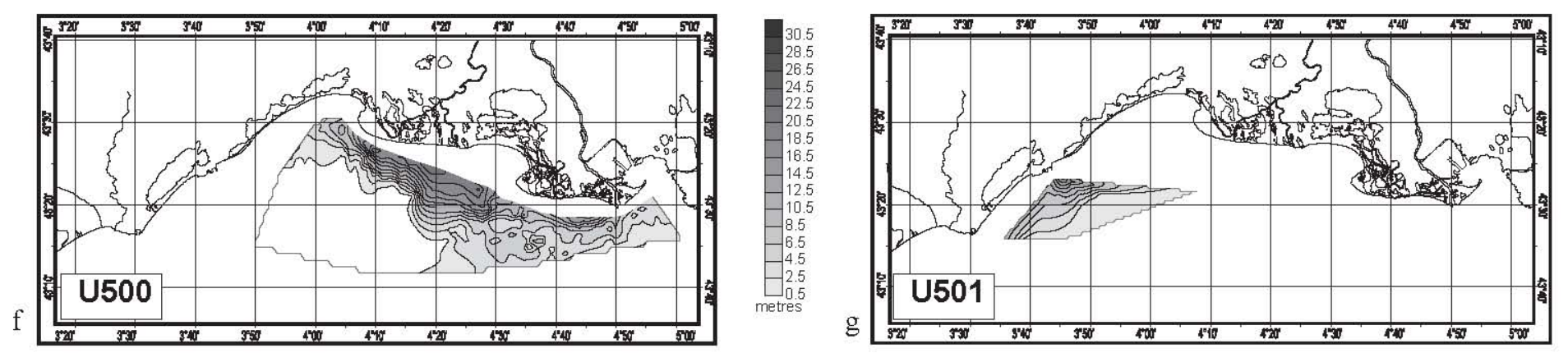

\section{$0 \quad 10 \quad 20 \mathrm{KM}$ \\ Mercator - WCS 84}
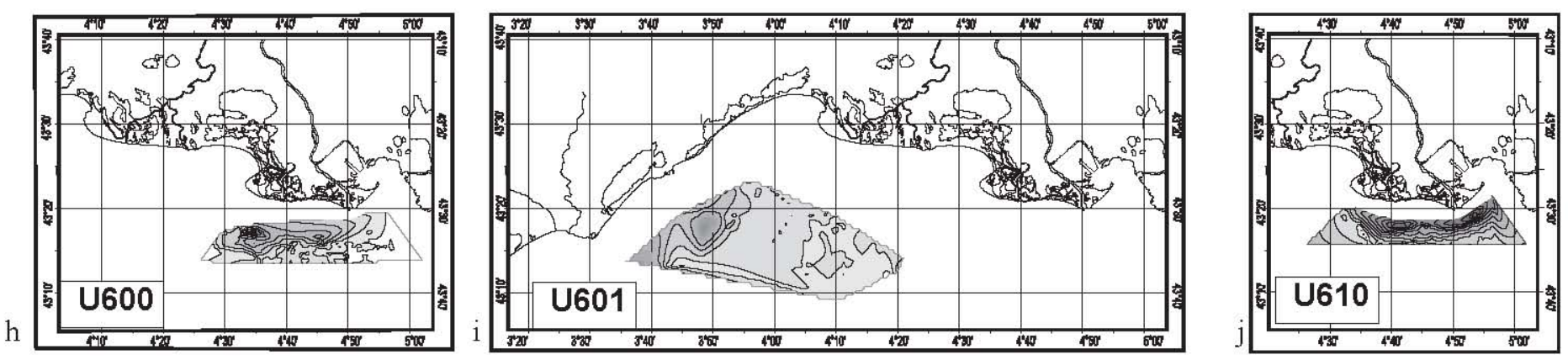

Fig. 6. Isopach maps of some of the units identified in the Rhône prodelta and adjacent shelf. The isopach maps from the sixth unit to the upper unit identified (from $\mathrm{f}$ to $\mathrm{j}$ ) are here shown. Thickness in meters, based on an acoustic waves velocity of $1600 \mathrm{~m} / \mathrm{s}$ in sediment. 


\section{Interpretation}

\subsection{Stratigraphic interpretation}

Two mains unconformities (Fig. 7) have been identified in terms of sequence stratigraphy (Mitchum et al., 1977).

(i) D200, which is merged with D300 in the western area, is located at the base of the Deglacial deposits. It is interpreted at once as the lowstand erosional discontinuity (Marsset and Bellec, 2002) and as the Transgressive Surface (TS).

(ii) The unconformity D600 which separates back-stepping units from aggrading/prograding units is a maximum flooding surface (mfs). In the central area, this surface is outcropping. In the western area the lateral equivalent of D600 (mfs) is represented by D601.

The other unconformities (D400, D500, D610) represent flooding surfaces.

On either side of the deltaic plain, the units rest on a Pliocene and Mesozoic substrate which has a relatively high gradient (1\% to 3\%). Three types of stacking pattern are observed (Fig. 7): (a) aggrading pattern in the eastern area, (b) backstepping pattern with mfs outcropping in the central area and (c) aggrading pattern with mfs outcropping in the westernmost area.

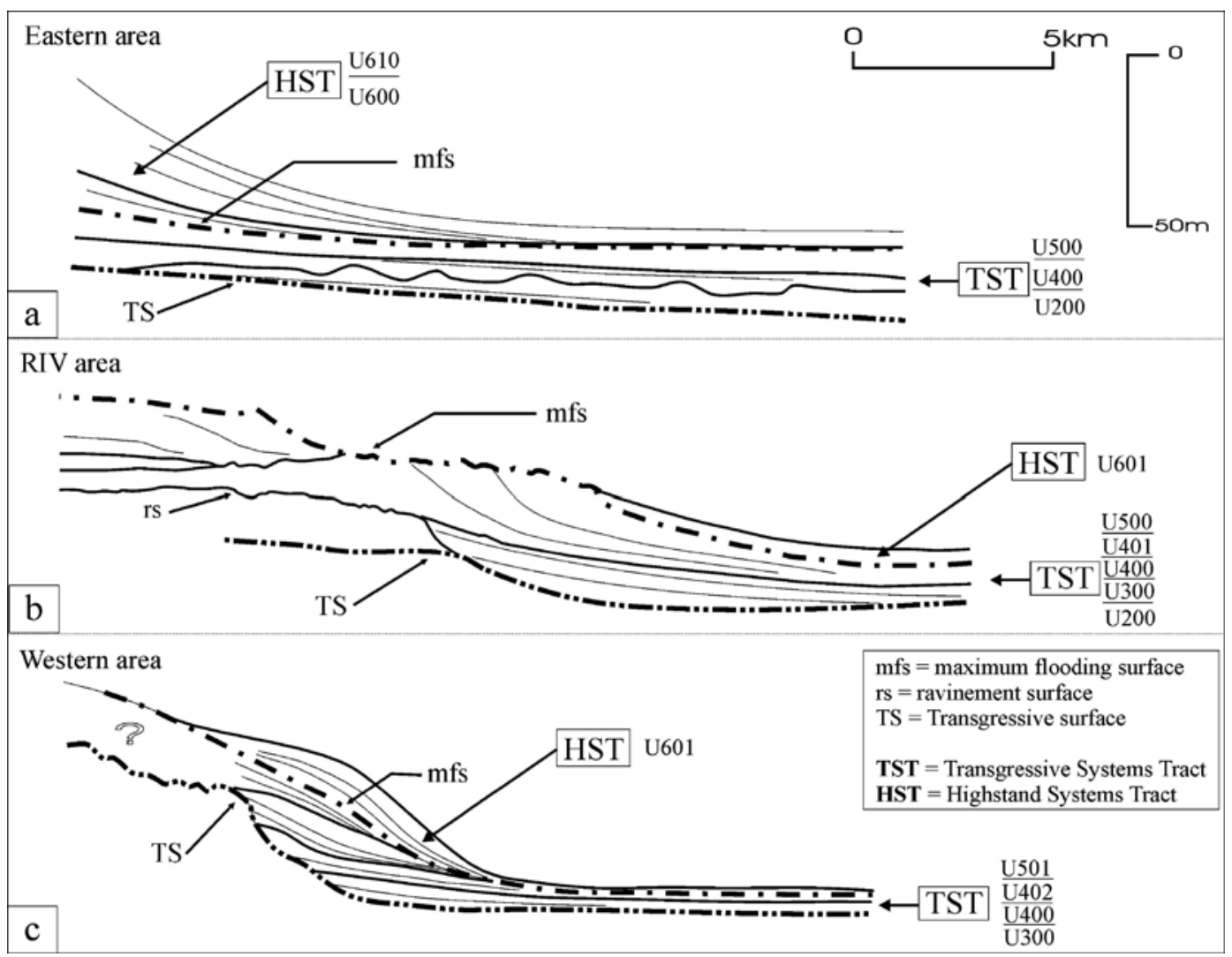

Fig. 7. Schematic patterns of the Deglacial deposits in each identified areas (a: eastern area, b: RIV area, c: western area). Location of key stratigraphic surfaces and systems tracts. 


\subsection{Depositional processes (environments)}

The basal seismic unit, U200, built along the retreat path of the Rhône mouth across the shelf. In the central part, seismic facies indicate coarse-grained deposits probably resulting from the reworking of alluvial deposits of the RIVC (Würmian terraces). To the east, the continuous reflectors are interpreted as medium to fine grained overflow deposits.

The transgressive pattern within unit U300 suggests that this unit developed during a period of rapid landward migration of the shoreline.

The two prograding units, U400 and U500, have similar attributes to modern coastal depositional systems. The seaward prograding clinoforms are typical of a sandy coastal barrier, with lagoonal deposits possibly preserved (Fig. 5b) landward. Locally, the sudden acoustic wipe out of seismic reflections observed seaward of the coastal barrier (Fig. 5d) is attributed to the effects of shallow gas. It is commonly found in rapidly deposited sediments with a high organic content such as prodelta environments. U400 and U500 are interpreted as coastal systems resulting from the progradation of deltaic lobes which have been subsequently reworked and reshaped into coastal barriers as it can be observed in the modern Rhône delta (Oomkens, 1967). Unit U401 may represent either backbarrier deposits synchronous of the U400 coastal system, or washover deposits associated with reworking of the top of U400 during the subsequent flooding event.

Units U400 and U500 prograded during periods of decreasing rate of sea level rise and/or increased sediment supply. These units are parasequences of the Transgressive Systems Tract (TST) bounded by flooding surfaces in the sense of Van wagoner et al. (1988); locally, the boundary of U400/U500 is a wave ravinement surface (D500). They are arranged in a backstepping pattern which reflects the transgressive character of the late Deglacial period. Because of their present bathymetric location (30 to $60 \mathrm{~m}$ ), below storm wave base, they are not presently subject to reworking.

Units U402 and U501 are considered as the lateral equivalents to U400 and U500, respectively. Regarding their shapes and internal reflectors, they are compared to ancestral "subaqueous deltas" in the sense of Cattaneo et al. (2003). They would have form under the effect of westward littoral drift and regional circulation, considered similar to the present-day oceanographic regime.

Units U600 and U610 constitute prodeltaic lobes. They correlate onshore with deposits of the upper part of the delta plain. They prograded onto the late transgressive deposits (U400 and U500) and they are interpreted as sedimentary bodies of the Highstand Systems Tract. Their lower boundary (D600) is the maximum flooding surface (mfs). Recent studies on the Rhone delta plain (Vella, 2002) show that at least two major Highstand delta complexes prograded during the last $4000 \mathrm{yr}$. The first one (Saint Ferreol complex) prograded between 4000 and $2000 \mathrm{yr}$ BP in the western part of the Rhône delta plain, in front of units U400 and U500. The most recent system (Vieux Rhône complex) prograded since 2000 yr BP in the eastern part of the delta plain and correlates seaward with units U600 and U610. The upper prodeltaic lobe, U610, shows two depocentres. The first depocentre is correlated with the "Bras de Fer" deltaic lobe and the second depocentre with the presently active lobe (Roustang lobe).

Unit U601 is also interpreted as a modern "subaqueous delta" in the sense of Cattaneo et al. (2003) because there is no direct sediment supply source in the vicinity. The Rhône would therefore be the main sediment source of U601, sediment being transported by a southwestward current generated by the Liguro-Provencal current. 


\section{Discussion}

\subsection{Glacio-eustacy}

Given the short time-span represented by the Deglacial deposits, and the moderate effect of tectonic subsidence in the area (Bessis, 1986) we consider that the main controlling factor on stratal architecture is related to glacio-eustatic sea-level changes. Nevertheless other controlling factors, especially sediment supply, ocean dynamics and the pre-existing morphology may have had an effect on the stacking pattern of the prodeltaic units.

It is now well-known that the last Deglacial sea level rise was not continuous and regular but was punctuated by steps (Fairbanks, 1989; Bard et al., 1993; Bard et al., 1996). In Lambeck and Bard

(2000), two sea-level variation models are presented. The first model represents a predicted relative sea-level curve which shows a regular relative sea-level rise along the French Mediterranean coast. The second model presents a corrected relative sea-level curve based on field observations and shows increased and decreased rate of relative sea-level rise.

On the Rhône shelf, the good correlation between the bathymetry of the upper boundaries of the transgressive units and the Deglacial sea-level curve suggests that glacio-eustatic changes are the main controlling factor.

\subsection{Deglacial development}

Unit U200, located along the axis of the paleo-Rhône, is observed all over the shelf (Gensous and Tesson, 2003), representing the retreating path of the Rhône delta.

Unit U300 built up during a period of rapid migration of the shoreline from outer to inner shelf (from $90 \mathrm{~m}$ to $70 \mathrm{~m}$ ). We correlate it with the meltwater pulse 1A (MWP-1A) that started at around 14,200 yr Cal. BP and occurred during 500 yr (Fig. 8). Moreover, the low gradient of the middle shelf, inherited from the previous lowstand period, favored the rapid landward shift of the shoreline, when the rate of eustatic sea-level rise increased dramatically.

Units U400 and U500 prograded during periods of slowing down of eustatic rise. Age dating from cores cutting across U400 gives $9860 \mathrm{yr}{ }_{14}^{14} \mathrm{C}$ BP/11,300 yr Cal. BP (Aloisi et al., 1975) and 10,475 F40 yr C BP/12,600 yr Cal. BP (Berne et al., 2003). From these data, it is assumed that U400 built up during the Younger Dryas after MWP 1A. Similarly, it would be proposed that U500 prograded during the period of decreased rate of sea-level rise that occurred after MWP 1B. However, the importance of this second meltwater pulse (MWP-1B) is controversial (Bard et al., 1996), and it is not absolutely certain that the backstepping pattern between U400/U500 is related to a changing rate of sea-level rise. Another possibility is that the progradation of U500 would be related to climatically induced increase in river supply.

Units U600 and U610 have prograded onto the late transgressive deposits since the period of reduced rate of sea-level rise at the end of the Holocene. A previous study of sea-level changes during the Highstand period that occurred in the delta plain (Vella and Provansal, 2000) indicates two periods of rapid sea-level rise. The first occurred between 6295 and $4585{ }^{14}$ yr C BP (about 2 $\mathrm{mm} / \mathrm{yr}$ ) and the second, between 2120 and $1200 \mathrm{yr}{ }^{14} \mathrm{C}$ BP (1.9 mm yr). These periods were separated by a period of stability between 4085 and 2260 yr ${ }^{14} \mathrm{C}$ BP during which the Saint Ferréol lobe prograded in the western part of the delta plain. From studies carried out on the delta 
(Vella, 2002), the two depocentres of Unit 610 are correlated with the "Bras de Fer" delta lobe that prograded during the 17th and 18th Century (that is the Little Ice Age period) during a period of enhanced sediment supply and the presently active "lobe de Roustang", that was artificially channelled at the end of the19th century.

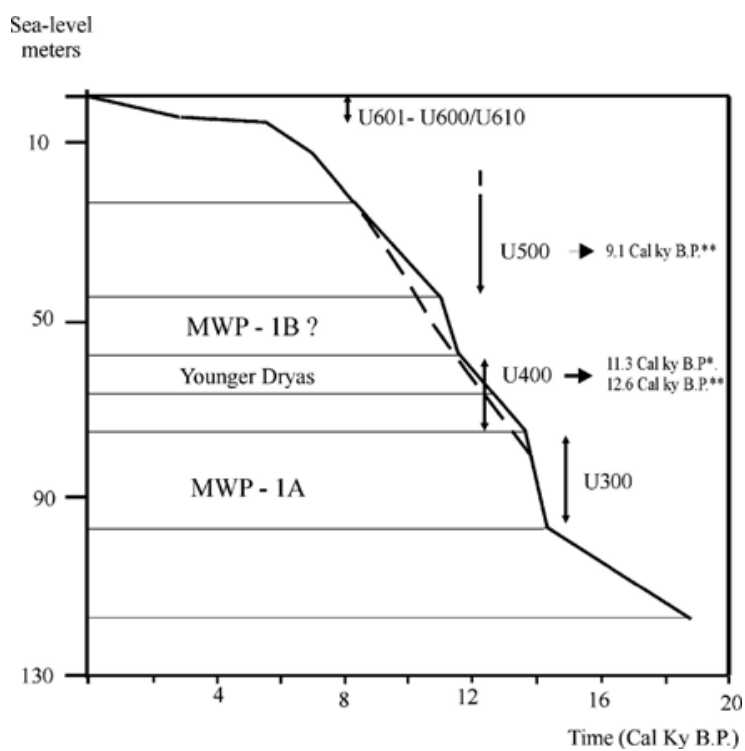

Fig. 8. Relation between glacio-eustacy and Deglacial units. Eustatic curves from Bard et al. (1996), showing the alternating period of increase and decrease rates of sea-level rise. MWP-1A and MWP-1B: brief periods of accelerated melting (i.e., meltwater pulse) of the continental ice and increase of sea-level rise. The continuous line presents the two MWP events whereas the dashed line presents a single MWP. YD: periods corresponding to the Younger Dryas cold period. *Age dating from Berne et al. (2003) corresponding to the unit U400, **age dating from Aloisi et al. (1975) corresponding, respectively to the units U500 and U400.

\subsection{Other controlling factors}

In the western area, units U402, U501 and U601 represent subaqueous deltas. In this work, they are considered as time correlative (synchronous) of units U400, U500 and U600/U610, respectively.

The development of a large prograding body rather than a subaqueous delta is correlated to the hydrodynamic conditions and to the variation in sediment supply. In front of the Rhône mouth the sediment discharge was sufficient to build up an important prograding deltaic depositional system with continuity between the deposits of the delta plain, delta front and prodelta. Westward to the Rhône mouth the sediment supply decreased. Nevertheless the general oceanographic circulation could lead to a westward transport of suspended sediment of the Rhône which enabledto build up a prograding body, the relict subaqueous delta which is disconnected from the modern coastal barrier.

In the central part, off the deltaic plain, the shelf has a low gradient $(0.1 \%$ to $0.5 \%)$ inherited from the deltaic plain environment of the previous lowstand period (and similar to the gradient of the Rhône river of the modern delta plain). This inherited topography favored the rapid landward migration of the shoreline during a phase of accelerated sea-level rise and the drowning of parasequences that are arranged in a retrogradational pattern (Fig. 7b). 


\section{Labaune et al./ Marine Geology xx (2005) xxx-xxx}

\section{Conclusions}

From the synthesis of existing seismic data, a succession of 10 units separated by flooding surfaces have been observedon the Rhône delta shelf. The first seven are associated to the Transgressive Systems Tract and the last three are associated to the Highstand Systems Tract (HST).

From base to top the TST is composed of (i) reworking deposits of Wu“ rmian terraces due to the first step of the Deglacial transgression, (ii) transgressive deposits due to the rapid sea-level rise and landward migration of the shoreline and (iii) two backstepping coastal systems. The first coastal system is due to a decrease in the rate of sea-level rise associated to the Younger Dryas event. The second coastal system is due to a decrease in the rate of the sea-level rise or to an important increase in the rate of sediment supply associated to a constant rate of sea-level rise.

The HST is composed of prograding delta lobes in the eastern area and subaqueous delta in the western area. The prograding delta lobes are due to minor sea-level variations during a stillstand sea-level, or, more probably, to lobe switching that could be linked to rapid climatic changes. The subaqueous delta is mainly fed by sediment supply reworked through the hydrodynamic circulation.

Glacio-eustacy seems to be the main factor controlling the overall stratigraphic organization of units. Good correlation exists between the shape of the global sea-level curve and the position of the units. Moreover, lateral variability observed within the Rhone sedimentary units would result from the ratio between the rate of sea-level rise and fluvial sediment supply, the location of the sediment input and differing slope gradients.

Without a detailed chronostratigraphic framework, it is difficult to disentangle effects from global (eustatic) changes and those due to local (climatic) changes. However, this study provides the first comprehensive view of the stratigraphic architecture of the Rhone prodelta, and provides the framework for future detailed sedimentological and paleoenvironmental studies.

\section{Acknowledgments}

This project was carried out within the Eurodelta Concerted Action funded by the European Community (Contract EVK3-CT-2001-20001).

The seismic data acquisition was supported by the French INSU-CNRS and Ifremer. Additional support came from the French bmarginsQprogram (GDR MArges). A regional grant supported by the Languedoc-Roussillon Region was attributed to C. L.

\section{References}

Aloïsi, J.C., 1986. Sur un modèle de sédimentologie deltaïque. Contribution à la connaissance des marges passives. Thèse d'état, Université de Perpignan. 161 pp.

Aloïsi, J.C., Monaco, A., Thommeret, J., Thommeret, Y., 1975. Evolution paléogéographique du plateau continental languedocien dans le cadre du golfe du Lion. Analyse comparée des données sismiques, sédimentologiques et radiométriques concernant le Quaternaire récent. Rev. Géogr. Phys. Géol. Dyn. XXXII (1), 13 - 22.

Bard, E., Arnold, M., Fairbanks, R.G., Hamelin, B., 1993. ${ }^{230} \mathrm{Th}-{ }^{234} \mathrm{U}{ }^{14} \mathrm{C}$ ages obtained from mass spectrometry on corals. Radiocarbon 35, $191-199$.

Bard, E., Hamelin, B., Arnold, M., Montaggioni, L., Cabioch, G., Faure, G., Rougerie, F., 1996. Deglacial sea-level record from Tahiti corals and the timing of global meltwater discharge. Nature 382, 241 - 244.

Berne, S., Lericolais, G., Marsset, T., Bourillet, J.F., De Batist, M., 1998. Erosional offshore sand ridges and lowstand shorefaces: examples from tide and wave dominated environments of France. J. Sediment. Res. 69 (4), $540-555$.

Berne, S., Baton, J.M., Delpeint, A., Dennielou, B., Duval, F., Field, M., Lericolais, G., Le Roux, E., Satra, C., Taviani, C., 2003. Deglacial history of the Rhone prodelta form detailed morphology and preliminary stratigraphic data. ComDelta: Open conference on Comparing Mediterranean and Black Sea Prodeltas. Aix-en- 


\section{Labaune et al./ Marine Geology xx (2005) xxx-xxx}

Provence, France, 26-28 October 2003.

Bessis, F., 1986. Some remarks on the study of subsidence of sedimentary basins. Application to the Gulf of Lions margin. Mar. Pet. Geol. 3, 37 - 63.

Cattaneo, A., Correggiari, A., Langone, L., Trincardi, F., 2003. The late-Holocene Gargano subaqueous delta, Adriatic shelf: sediment pathways and supply fluctuations. Mar. Geol. 193 (1-2), 61 - 91.

Gensous, B., Tesson, M., 1997. Les dépôts postglaciaires de la plate-forme rhodanienne: organisation stratigraphique et conditions de mise en place. C. R. Acad. Sci., Paris II (317), $803-810$.

Gensous, B., Tesson, M., 2003. L'analyse des dépôts postglaciaires et son application à l'étude des séquences de dépôt du Quaternaire terminal sur la plate-forme au large du Rhône (Golfe du Lion). Bull. Soc. Géol. Fr. 174, 401 $-419$.

Gueguen, E., 1995. La Méditerranée Occidentale: un véritable océan. Exemple de segmentation des marges et de hiatus cinématiques. Implications sur les processus d'amincissement crustal. Thèse de doctorat, Université de Bretagne Occidentale.

Fairbanks, R.G., 1989. A 17000-year glacio-eustatic sea level record: influence of glacial melting rates on the Younger Dryas event and deep-ocean circulation. Nature 342 (6250), 637 - 642.

Lambeck, K., Bard, E., 2000. Sea-level change along the French Mediterranean coast for the past 30000 years. Earth Planet. Sci. Lett. 175 (3-4), 203 - 222.

Marsset, T., Bellec, V., 2002. Late-Pleistocene-Holocene deposits of the Rhône inner continental shelf (France): detailed mapping and correlation with previous continental and marine studies. Sedimentology 49, 255 - 276.

Millot, C., 1994. Models and data: a synergetic approach in the Western Mediterranean sea. In: Malanotte-Rizzoli, P. (Ed.), Ocean Processes in Climate Dynamics: Global and Mediterranean Examples. Kluwer Academic Publishers, pp. $407-425$.

Mitchum, J.R., Vail, P.R., 1977. Seismic stratigraphy and global changes of sea level: Part 7. Seismic stratigraphy interpretation procedure. In: Payton, C.E. (Ed.), Seismic Stratigraphy- Applications to Hydrocarbon Exploration, 26, Mem. AAPG, pp. 135 - 143.

Mitchum, J.R., Vail, P.R., Sangree, J.B., 1977. Seismic stratigraphy and global changes of sea level, part: stratigraphic interpretation of seismic reflection patterns in depositional sequences. In: Payton, C.E. (Ed.), Seismic Stratigraphy-Applications to Hydrocarbon Exploration (Ed. Payton, C.E.), 26, Mem. AAPG, pp. 117133.

Oomkens, E., 1967. Depositional sequences and sand distribution in a deltaic complex. Geol. Mijnb. 46, 265 - 278.

Pont, D., Simonnet, J.-P., Walter, A.V., 2002. Medium-term changes in suspended sediment delivery to the ocean: consequences of catchment heterogeneity and river management (Rhone River, France). Estuar. Coast. Shelf Sci. 54 (1), 1- 18.

Posamentier, H., Allen, G., James, D.P., Tesson, M., 1992. Forced regressions in a sequence stratigraphic framework: concepts, examples, and exploration significance. AAPG Bull. 76, 1687 - 1709.

Rabineau, M., Berne, S., Ledrezen, E., Lericolais, G., Marsset, T., Rotunno, M., 1998. 3D architecture of lowstand and transgressive Quaternary sand bodies on the outer shelf of the Gulf of Lion, France. Mar. Pet. Geol. 15 (5), $439-452$.

Sioni, S., 1997. Mer Ionienne et Apulie depuis l'ouverture de l’Océan Alpin. Thèse de Doctorat, Univ. Bretagne Occidentale.

Speranza, F., Villa, I.M., Sagnotti, L., Florindo, F., Cosentino, D., Cipollari, P., Matei, M., 2002. Age of the CorsicaSardinia rotation and Liguro-Provencal Basin spreading: new paleomagnetic and Ar/Ar evidence. Tectonophysics $347,231-251$.

Tesson, M., Allen, G., 1995. Contrôle tectonique et eustatique haute-fré quence de l'architecture et de la stratigraphie de dépôts de plate-forme péricatonique. Exemple du Golfe du Lion (Méditerranée, France) et des dépôts quaternaires. C. R. Acad. Sci., Paris IIa (320), 39 - 46.

Tesson, M., Posamentier, H., Gensous, B., 2000. Stratigraphic organization of the Late Pleistocene deposits of the western part of the Golfe du Lion shelf (Languedoc shelf), western Mediterranean Sea, using high resolution seismic and core data. AAPG Bull. 84 (1), 119- 150.

Trincardi, F., 2003. The impact of short term supply fluctuations on margin shaping over the last 20,000 years. Ocean Margin Research Conference, Paris 15th-17th September 2003.

Van wagoner, J.C., Posamentier, H.W., Mitchum Jr., R.M.Vail, P.R., Sarg, J.F., Loutit, T.S., Hardenbol, J., 1988. An overview of the fundamentals of Sequence Stratigraphy and key definitions. In: Wilgus, C.K., Hastings, B.S., Kendall, C.G.St.C., Posamentier, H., Ross, C.A., Van Wagoner, J. (Eds.), Sea Level Changes- An integrated approach. SEPM Special Publication, vol. 42, pp. 39- 46.

Vella, C., 2002. Edification pulsé e d’un appareil prodeltai"que progradant: le lobe de St. Ferréol, delta du Rhône. Colloque géné ral du GDR marges, Reuil Malmaison.

Vella, C., Provansal, M., 2000. Relative sea-level rise and neotectonic event during the last $6500 \mathrm{yr}$ on the southern eastern Rhône delta. Mar. Geol. 170, 27 - 39. 